\title{
Onomatopoeia and Direct Speech on the Narratives of Deaf and Hearing Students
}

\author{
Marsandi Manar ${ }^{1, *}$ Dadang Sudana ${ }^{1}$ Iwa Lukmana $^{1}$ \\ ${ }^{1}$ Linguistic Study Program, School of Postgraduate, Universitas Pendidikan Indonesia, Bandung, Indonesia \\ ${ }^{*}$ Corresponding author.Email: manarmarsandi17@gmail.com
}

\begin{abstract}
This comparative linguistic scrutiny attempts to reveal the phenomena of onomatopoeia and direct speech on the Indonesian narrative compositions produced by deaf and hearing students. Eight personal narratives about being chased by a dog were elicited from eight deaf senior high school students and 12 were gathered from their hearing counterparts of the same level. Both data sets were analysed for their adoption of onomatopoeia and direct speech. The qualitative analysis reveals that none of onomatopoeia and direct speech was employed in the writings of all deaf students. In the stories of their hearing counterpart, 7 of 12 narratives contain onomatopoeia and 4 contain direct speech. The onomatopoeia covers the sounds of animal, human, and tool while the direct speech consists of conversations and one-way comments made by participants involved in the stories. The findings of this study emphasise that deaf student writers in comparison with their hearing counterparts were less likely to incorporate onomatopoeia and direct speech into their writings. It is speculated that the absence of both language features in the narrative compositions of deaf students correlates with their inaccessibility to the direct verbal language. Though the findings of the current study are not conclusive due to its specific context and limited numbers of participants, at least they are expected to contribute to the language teaching and learning especially related with the development of written literacy for deaf student writers. Language teaching and learning in the classroom is expected to assist deaf students in employing onomatopoeia and direct speech in their narratives to make their stories more functional and interesting to read.
\end{abstract}

\section{Keywords: Onomatopoeia, Direct speech, Narratives, Deaf, Hearing, Students}

\section{INTRODUCTION}

For the past decade, the concern on the literacy skills has been growing towards the spirit of inclusiveness where all individuals of global citizen are expected to be given the same opportunity to equally participate in the society. This recently gained momentum has widened the chances for any individuals regardless of their differences to be not only the consumers of literacy product but also as its producer or creator. A particular type of community that has recently been the centre of attention in terms of literacy development is people with special needs especially those participating in the educational settings. Students with special needs either in the school context or outside the academic world cannot avoid participating in their literate environment.

One of the most salient tools for taking part in the literate community is the ability to empower and benefit from language skills, either written or spoken. Unfortunately, for certain community like the deaf, there is very limited even no access to the verbal language except mainly via sign and written language. Deafness or hearing limitation in general can be understood as the inability to hear either half or totally.
It is further categorised based on its levels of hearing loss, namely from 26 to $40 \mathrm{~dB}$ loss as mild level, 41 to $55 \mathrm{~dB}$ as moderate, 56 to $70 \mathrm{~dB}$ as moderately severe, 71 to $90 \mathrm{~dB}$ as severe, and that above $90 \mathrm{~dB}$ as profound level [1]

Due to the fact that deaf individuals have limited or no access to the verbal language and rely mainly on written and sign language instead, a plethora of effort for assisting the deaf community to write well has been conducted especially by means of empirical research. To date, studies on the texts of deaf writers have generally been divided into two shafts, that is, teaching and learning research focusing on how to help them compose functional writings and linguistic studies concentrating on their language nature, challenges, and difficulties. Ideally, the former can be perfectly conducted after the latter. This means that to be able to help deaf writers especially students to write like the way their hearing counterpart do, teachers at the initial phase need the scientific insight into the language nature of their students. These language characteristics can only be revealed cogently by the linguistic studies. 
To the present time, studies on the linguistic phenomena of deaf writers have significantly made use of narrative writings. The reason behind this notion might be related with the nature and functions of narratives that demand writers to not only portray the introduction to an event or character but also to construct problematic case then finally to provide resolution to the problematic experience. In a simple way, this genre of writing can allow a deaf writer to train their critical thinking and problem solving. As it has been known, the genre of narratives can be associated with a sequence of a single story that has three basic specific functions of introducing a case or character, revealing the problematic phenomenon, and providing resolution to the problem [2], [3].

Further, the genre of narrative aims to entertain reader or listeners, establish moral values, and to disseminate a lesson [2]. This genre is a part of creative writing since it enables writers to construct problematic event in reference to their personal experience or imaginary world [4]. Through the genre of narrative, writers are demanded to position themselves both as the readers and simultaneously as the characters in the story. In relation with deaf writers especially students, this type of writing can assist them how to build their interpersonal skills. As underpinned by previous studies, deaf writers to some extents have difficulties in position their mental as others' [5], [6], due to their limited access to their social environment mediated by verbal language. Deaf children of 4-13 years old, to illustrate, have been shown to have the lower level of empathy in comparison with their hearing counterparts of the same age [6], while 94 college students compared with their 41 hearing counterparts have also reported to have the lower level of performance level in terms of sarcasm, advanced false belief, and cognitive abilities [5].

Until now, it has been found that the narrative compositions of deaf students often reflect language difficulties. Some investigations have revealed that deaf students' narrative writings were often associated with errors in the adoption of subordinate clauses [7]-[9]. Another phenomenon of linguistic features found in the written narratives of students with deafness refers to problems in employing affixes and appropriate verbs [10]. This study specifically reported that deaf students' Indonesian verbs in narratives written based on a prompted video tended to be general in comparison to those in the oral and original version.

Among the linguistic features in the genre of narrative, the two that assist in constructing a functional story refer to onomatopoeia and direct speech. Both language features serve to make a story more real and concrete as they refer to more direct representation of communication. Either onomatopoeia or direct speech allows readers to go to the more direct reference of a character in an event or story. Concerning the former, it has been argued that it also functions as an aesthetic tool in depicting a story [11].

Theoretically, onomatopoeia can be seen as "words that are considered by convention to be imitative of nature, acoustically similar to the thing to which it refers (e.g. the bowwow of a dog or the tick-tock of a clock) or the sound made by the thing to which it refers (e.g. a buzz saw)"'[12]. It can be also formulated as the textual representation resembling with the natural sound [13]. Slightly different with onomatopoeia, direct speech can be defined as "a style used to report what a speaker actually said, without introducing any grammatical changes" [12]. In English including Indonesian, direct speech is characterised by double quotation marks that come before and after the expressions.

To date, the phenomena of onomatopoeia in narratives composed by deaf and hearing writers have not been investigated. Studies on this linguistic feature are overall outside that context. Under the genre of Japanese manga, for example, an investigation has revealed that onomatopoeia was proved to enhance the functionality of the texts in relation to the readers [11]. The study specifically exemplified that it helped in emphasising the representation of tsunami and then build more impressions of meaning on the readers. Meanwhile the investigation of Viana \& Zyngier (2019) on iconicity has claimed that by means of this linguistic feature student writers in the study were assisted in depicting their writings especially poems more creative, functional, and engaging. Their study however did not specifically focus on onomatopoeia which is a part of iconicity, rather on the iconicity itself.

Another previous study has related onomatopoeia with infant's phonological development [15]. The longitudinal study on a single infant participant further claimed that onomatopoeic words contribute to the wider lexical and phonological development. The result of this study, however, has little significance for the context of higher literacy especially narratives.

Like onomatopoeia, direct speech in the narrative written by deaf and hearing students has been less even not investigated as well. The phenomena of this language feature have been evaluated based on other contexts. An experimental study, to illustrate, has focused on the function of direct speech in relation to cognitivism [16]. The study further reported that the adoption of direct speech in comparison to the indirect one resulted in the stronger mental representation of the exact utterances. In other words, the utterances are more memorable or easier to remember than indirect speech. In terms of narratives in general, a corpus-based study 
on the amount of direct speech employed in nineteencentury British novels claimed that by means of direct speech the characters as well as their significance on a story can be understood or estimated [17]. In another literary product like poem, it has been reiterated by a review study that the direct speech in old English poet could be employed to avoid subjective characterisation so that the characters could be easily understood by readers [18].

Viewed in terms of writers with language disorder especially aphasia, the direct speech in narratives has been shown to not only play roles in the liveliness of a story [19] but also in increasing the focus of the listeners [20]. The latter specifically found that participants with Broca's aphasia tended to employ direct speech without reporting verbs while those with anomic aphasia were inclined to adopt reporting verbs in their direct speech. For participants with aphasia, direct speech has been claimed to be a natural and economical language strategy in maintaining their narrative conversation with the listeners.

In the case of deaf students, linguistic studies on the narratives composed by that community can also involve the data from their hearing counterparts as the reference. The notion behind this is not to genuinely compare the language skills of both since they are incomparable or not apple to apple. The plausibility behind this comparison rather is to provide the insight into the gap between both or the difficulties encountered by deaf writers. Thus, in the further phase any writing treatments can be provided to assist them in writing at least like the way their hearing counterparts do.

To date, two of linguistic features that have not been investigated under the genre of narratives of deaf and hearing writers have been associated with the adoption of onomatopoeia and direct speech. These both linguistic features so far have only been scrutinized under other contexts as explained before. Hence there is a need to investigate the phenomena of onomatopoeia and direct speech on the written narratives produced by deaf writers in reference to those composed by their hearing counterparts. This qualitative text analysis study therefore attempts to delineate the adoption of onomatopoeia and direct speech in the personal narratives of deaf and hearing senior high school student writers by answering the following question: what onomatopoeia and direct speech are employed by deaf and hearing student writers in their personal narratives about being chased by a dog.

\section{METHOD}

The method applied in the current comparative linguistic study refers to qualitative text analysis examining the Indonesian narrative compositions under the case of deaf and hearing students in terms of their onomatopoeia and direct speech. The relevant details of deaf and hearing participants involved in the study are provided in the two following table.

Table 1. Background information of deaf senior high school students

\begin{tabular}{|c|c|c|c|c|c|c|}
\hline No. & $\begin{array}{c}\text { Initial of Deaf } \\
\text { Students }\end{array}$ & $\begin{array}{l}\text { Level of } \\
\text { Deafness }\end{array}$ & Cause of Deafness & $\begin{array}{c}\text { First } \\
\text { Diagnosis }\end{array}$ & Age & Sex \\
\hline 1 & AA & profound & febrile seizure & $\begin{array}{ll}\text { since two } \\
\text { years old }\end{array}$ & 24 years +3 months & male \\
\hline 2 & $\mathrm{AP}$ & profound & Rubella virus & since at birth & 17 years +4 months & female \\
\hline 3 & AR & profound & high fever & $\begin{array}{l}\text { since eight } \\
\text { months old }\end{array}$ & 20 years & male \\
\hline 4 & AAP & profound & drugs & $\begin{array}{l}\text { since one year } \\
\text { old }\end{array}$ & 18 years +9 months & female \\
\hline 5 & $\mathrm{UJ}$ & profound & frequent illness after birth & since at birth & 18 years +4 months & female \\
\hline 6 & $\mathrm{NN}$ & profound & Rubella virus & since at birth & 19 years +2 months & female \\
\hline 7 & $\mathrm{NF}$ & profound & Rubella virus & since at birth & 17 years +1 month & female \\
\hline 8 & NT & profound & not-known & since at birth & 17 years +8 months & female \\
\hline
\end{tabular}

Table 2. Background information of hearing senior high school students

\begin{tabular}{|l|l|l|l|}
\hline No. & $\begin{array}{l}\text { Initial of } \\
\text { Hearing } \\
\text { Students }\end{array}$ & Age & Sex \\
\hline 1 & FK & 16 years +8 months & female \\
\hline 2 & IR & 17 years +5 months & female \\
\hline 3 & IS & 17 years +2 months & male \\
\hline 4 & KT & 16 years +1 month & female \\
\hline
\end{tabular}

\begin{tabular}{|l|l|l|l|}
\hline 5 & NA & 15 years +6 months & female \\
\hline 6 & NM & 17 years & female \\
\hline 7 & NP & 16 years & female \\
\hline 8 & RM & 15 years +8 months & female \\
\hline 9 & RP & 15 years +10 months & male \\
\hline 10 & SS & 15 years +11 months & female \\
\hline 11 & SZ & 17 years +6 months & female \\
\hline 12 & VO & 16 years +4 months & female \\
\hline
\end{tabular}


Eight personal narratives about being chased by a dog were elicited from eight deaf senior high school students and twelve were also elicited from their hearing counterparts of the same level. The data elicitation of the former was assisted by a teacher who masters Indonesian sign language.

Then the elicited stories were initially analysed in terms of the three basic generic structure of narrative, namely orientation, complication, and resolution. The subsequent analysis was executed by marking onomatopoeia and direct speech utterances. Further, they were categorised based on their own specific types.

\section{FINDING \& DISCUSSION}

The purpose of this qualitative text-analysis study is to delineate the phenomena of onomatopoeia and direct speech in the Indonesian narrative compositions produced by deaf and hearing senior high school students. The answers to this purpose of study are portrayed in the following tables.

Table 3. Onomatopoeia and direct speech phenomena in deaf students' narratives

\begin{tabular}{|c|c|c|c|}
\hline No. & $\begin{array}{c}\text { Initial of } \\
\text { Hearing } \\
\text { Students }\end{array}$ & Onomatopoeia & $\begin{array}{c}\text { Direct } \\
\text { speech }\end{array}$ \\
\hline 1 & AA & - & - \\
\hline 2 & AP & - & - \\
\hline 3 & AR & - & - \\
\hline 4 & AAP & - & - \\
\hline 5 & UJ & - & - \\
\hline 6 & NN & - & - \\
\hline 7 & NF & - & - \\
\hline 8 & NT & - & \\
\hline
\end{tabular}

Table 4. Onomatopoeia and direct speech phenomena in hearing students' narratives

\begin{tabular}{|c|c|c|c|}
\hline No. & $\begin{array}{c}\text { Initial of } \\
\text { Hearing } \\
\text { Students }\end{array}$ & Onomatopoeia & $\begin{array}{c}\text { Direct } \\
\text { speech }\end{array}$ \\
\hline 1 & FK & V & V \\
\hline 2 & IR & V & V \\
\hline 3 & IS & - & - \\
\hline 4 & KT & V & - \\
\hline 5 & NA & - & - \\
\hline 6 & NM & V & - \\
\hline 7 & NP & - & - \\
\hline 8 & RM & - & - \\
\hline 9 & RP & V & - \\
\hline 10 & SS & V & V \\
\hline 11 & SZ & V & V \\
\hline 12 & VO & - & \\
\hline
\end{tabular}

As depicted in both tables above, neither onomatopoeia nor direct speech was found in the narrative compositions written by deaf senior high school students participated in the current study. In the data set of their hearing counterparts, seven narratives employ onomatopoeia and four adopt direct speech. The direct speech refers to one-way and two-way comments made by participants involved in the stories as shown in the following extracts.

\section{One-way comments}

ibu saya bilang "udah besar, malah takut anjing" (Data-IR)

my mother said "not a kid anymore, but afraid of dogs" (Data-IR)

"makanya Jangan iseng" celetuk kak putri. (Data-SZ) "should not have teased it," said my elder sister Putri. (Data-SZ)

\section{Two-way comments}

"Vania main yuk!", katanya Aku pun keluar dan berkata "Tunggu sebentar". (Data-VO)

"Vania let's play!", she said so I went out and said "Wait a minute". (Data-VO)

Fanny : "iya sama sama." "Eh bar, ada kucing tuh disamping toko."

Akbar : (menoleh). "itu bukan kucing fan, tapi anjing (sambil berteriak). larii

(Data-FK)

Fanny: "anytime" "Eh bar, there's a cat next to the shop."

Akbar: (looks up). "It's not a cat fan, but a dog (while screaming). Run away Fann!." (Data-FK)

Further, in terms of the second linguistic feature addressed by the current study, the onomatopoeia found in the data set of hearing student writers encompass the sounds of an animal (dog's barking), the sounds of human (e.g., laughing), and the sound of tool (bike's ringing) as provided below.

\section{The sound of animal}

Dalam perjalanan ke toko, saya melewati rumah berwarna putih dan mendengar suara anjing "guk... guk... guk..". (Data-IR)

On my way to the store, I passed a white house and heard a dog sound "woof...woof...woof...". (IR-Data)

"guk-guk" suara itu mulai terdengar, ternyata anjing itu tidak dirantai, aku dan manda berlari karena dikejar anjing itu. (Data-SZ)

"woof-woof" the voice began to sound, in fact the dog was not chained, Manda and I ran because we were chased by the dog. (Data-SZ) 


\begin{abstract}
"Guk guk guk" ia menggonggong ke arahku, dan pada saat itu Aku Ketakutan dan langsung berlari, ternyata Anjing itu mengejarku. (Data-KT)

"Woof woof woof" it barked at me, and at that moment I was scared and ran straight away, truly the Dog chased me. (Data-KT)
\end{abstract}

\section{The sound of human}

Hahaha Kami pun berlari sekancang mungkin sambil terbahak-bahak. (Data-NM)

Hahaha then We ran as fast as possible while laughing. (Data-NM)

Ternyata kata orang itu, itu anjing gila, hemmm, untung saja saya tidak digigit sama anjing itu. (Data-RP)

Truely the person said, it was a rabies dog, hmmm, luckily I wasn't bitten by that dog.(Data-RP)

Ia melemparkan ranting sambil mengusir dengan kata "hush" kepada kedua anjing tersebut. (DataSS)

He threw a twig while shooing the two dogs away with the word "hush". (Data-SS)

\section{The sound of tool}

kring kring kring. Ada sepeda pink lewat dengan orang yang mengendarai dan orang dibelakangnya. (Data-FK)

ring ring ring. There was a pink bicycle passing by with a person riding it and a person in the rear carrier. (Data-FK)

As depicted in the findings above, hearing senior high school students in constructing their narratives employed three types of onomatopoeia and two categories of direct speech where all of these were not found in the data set of their deaf counterparts. The absence of these two language features in the narrative composed by the eight deaf participants might correlate with their inaccessibility to the more 'direct' reference representing the thing or object in their environment. This means that in order to be able to make narratives more functional with onomatopoeia and direct speech, writers firstly are needed to be exposed to the language 'model' used directly and originally in the environment, but unfortunately for deaf writers they in general only get the indirect reference of utterances from their environment. To illustrate, they are mainly more accessible to 'to bark' rather than 'woof woof woof'. In non-deaf writers, they have passed the phase of direct exposing to the environment and then the stage of connecting the real sounds in the environment with the utterances that resemble them. In reference to this notion, as one of strategies to connect them and their readers, deaf writers can be provided or treated with the verbal symbols resembling the real sounds of an object or thing.

To the present time, there has been the lack of knowledge based on previous or existing literature reporting the adoption of onomatopoeia and direct speech by deaf student writers in their writings. Hence it is still a challenge for this current study to relate its findings directly to other previous related findings. At least, the insight into the phenomena of onomatopoeia and direct speech of deaf writers can be related to another special and clinical context, for example, aphasia. Individuals with anomic aphasia in comparison with those of Broca's aphasia tended to construct a complete direct speech with reporting verb in their speaking [20]. In contrary, the latter tended to only use the direct speech without a reporting verb in constructing meaning [20]. In the case of aphasia, the limitation lies on the brain while in the context of deafness the problem is in the auditory perception functioning as allowing the accessibility of verbal representation mediating the environment. Though both cases are different, what can be noticed is that clinical problems either in the perceptive or processing 'tool' can trigger the linguistic nature including challenges encountered by the individuals with the limitation.

In relation to the narrative, as proved by previous studies, this type of genre needs onomatopoeia and direct speech as the two of strategies to achieve its functional goal. Onomatopoeia in Japanese Manga has been proved to play roles in building stronger representation of a thing, event, or phenomena as well as stronger impression to the readers [11]. In the wider context, iconicity in the literary product has been associated with its function in constructing meaning with more creative and engaging ways [14].

Like onomatopoeia, direct speech in the literary product has been claimed to play roles in helping readers to estimate the characterisation of a character along with its significance [17]. It also helped readers to easily understand the character accurately since the adoption of linguistic feature can avoid subjective characterisation coming from writers [18]. For aphasia narrators, the direct speech in oral narratives has been proved to increase the liveliness of the story [19] as well as the focus of the listeners [20]. The direct speech in general has been claimed to serve as creating stronger mental representation of the exact words, resulting in more recognized and long-lasting utterances in the hearers or readers' mind [16].

Finally, though the present study found none of onomatopoeia and direct speech in the narratives of deaf 
writers, it cannot be claimed that this type of students do not have both linguistic features in their mind. What can be noticed is that deaf writers compared to their hearing counterparts were less likely to incorporate onomatopoeia and direct speech into their narratives. Hence it is expected that deaf student writers will be specially and explicitly taught these two linguistic features in constructing their narrative compositions.

\section{CONCLUSION}

The final goal of this qualitative text analysis case study is not to genuinely compare the written narratives constructed by deaf and hearing senior students since they are incomparable or not apple to apple. Rather, the findings of the current scrutiny are expected to provide the insight into the gap of linguistic features, namely onomatopoeia and direct speech between both data sets so that at further phase any language treatment can be formulated and provided to assist the deaf writers in minimising the gap. The analysis of this study has revealed that deaf writers in comparison to their hearing counterparts were less likely to employ onomatopoeia and direct speech in their stories. Existing or previous literature has claimed both as two of salient linguistic strategies in obtaining the functional goal of narratives. It is expected that at least the deaf writers can narrate their stories like the ways in which their hearing counterparts do though the writings of the latter are also considered as the developing writings. This further expectation relies on Indonesian language teachers as the ones who have expertise and capacity in assisting their deaf writers to compose narratives functionally.

Despite its significance, the findings of this investigation are not conclusive due to the limited participants of study. Besides, this study only focused on the case of students in one public senior high school and two public special-need schools run but the Indonesian government. The results might or might not be generalizable to other contexts and cases. For further knowledge development, subsequent studies can focus on the same linguistic features by making use of other genres apart from narratives with the larger numbers of participants. Other studies may also extend the issue by adopting another method like experiment, for example, to confirm if direct speech for deaf writers is more difficult to master than indirect speech.

\section{AUTHORS' CONTRIBUTIONS}

This research was completed with the guidance of the second and third authors who are also the dissertation advisors of the first author.

\section{ACKNOWLEDGMENTS}

This work could not be accomplished without the deaf and hearing students who were willing to participate in writing their stories. It was also successfully carried out due to the assistance of the teachers who have coordinated their students with the researchers. Therefore, we would like to express our deep gratitude to all parties of the three different schools where the data of the current study were taken.

\section{REFERENCES}

[1] M. Marschark, H. G. Lang, and J. A. Albertini, Educating deaf students: From research to practice. New York: Oxford University press, 2002.

[2] L. Gerrot and P. Wignell, Making sense of functional grammar. Cammeray, New South Wales: Gerd Stabler, 1994.

[3] P. Knapp and M. Watkins, Genre, text, and grammar. Technology for teaching and assessing writing. Sydney: University of New South Wales Press, 2005.

[4] M. C. N. Cruz, "The role of systemic functional grammar in the expansion of nominal groups," Profile Issues Teach. Prof. Dev., vol. 21, no. 2, pp. 97-112, 2019, doi: 10.15446/profile.v21n2.73796.

[5] M. Marschark, L. Edwards, C. Peterson, K. Crowe, and D. Walton, "Understanding theory of mind in deaf and hearing college students," J. Deaf Stud. Deaf Educ., vol. 24, no. 2, pp. 104-118, 2019, doi: 10.1093/deafed/eny039.

[6] C. C. Peterson, "Empathy and theory of mind in deaf and hearing children," J. Deaf Stud. Deaf Educ., pp. 141-147, 2016, doi: 10.1093/deafed/env058.

[7] L. M. Bowers, H. Dostal, K. A. Wolbers, and S. C. Graham, "The assessment of written phrasal constructs and grammar of deaf and hard of hearing students with varying expressive language abilities," Educ. Res. Int., vol. 2018, pp. 1-10, 2018.

[8] L. A. Terugi and R. Gutierrez-Caceres, "Narrative skills in written texts by deaf and hearing bilingual adolescents," Read. Psychol., vol. 36, pp. 643-672, 2015, doi: 10.1080/02702711.2014.933149.

[9] K. A. Wolbers, H. M. Dostal, and L. M. Bowers, “"“ I was born full feaf ." Written language outcomes after 1 year of strategic and interactive writing instruction," J. Deaf Stud. Deaf Educ., vol. 17, no. 1, pp. 19-38, 2012, doi: 10.1093/deafed/enr018.

[10] A. P. Lintangsari, W. Widodo, and R. A. Kuswoyo, "Keterampilan narasi siswa tuli pada tingkat mikro," Linguist. Indones., vol. 37, no. 2, 
pp. 159-168, 2019, doi: 10.26499/li.v37i2.107.

[11] O. Rohan, R. Jackson, and R. Sasamoto, "Argumentation , relevance theory and persuasion," Int. Rev. Pragmat., vol. 10, pp. 219242, 2018, doi: 10.1163/18773109-01002005.

[12] J. C. Richards and R. Schmidt, Longman dictionary of language teaching and applied linguistics, 3rd ed. Edinburgh: Pearson Education Limited, 2002.

[13] L. Ellestrom, "Visual iconicity in poetry: replacing the notion of "visual poetry," Orb. Litt., vol. 71, no. 6, pp. 437-472., 2016.

[14] V. Viana and S. Zyngier, "Creative writing and iconicity in English as a foreign language," New Writ., vol. 16, no. 1, pp. 38-49, 2019, doi: https://doi.org/10.1080/14790726.2018.1476554.

[15] C. E. Laing, "A phonological analysis of onomatoeia in early word production," SAGE J., vol. 34, no. 5, 2014, doi: https://doi.org/10.1177/0142723714550110.

[16] A. Eerland, J. A. A. Engelen, and R. A. Zwaan,
"The influence of direct and indirect speech on mental representations," PLoS One, vol. 8, no. 6, 2013, doi: 10.1371/journal.pone.0065480.

[17] T. Menon, "Keeping count: Direct speech in the nineteenth-century british novel," Narrative, vol. 27, no. 2, pp. 160-181, 2019.

[18] L. Neidorf, "Direct speech in Beowulf and other old English narrative poems.," English Stud., vol. 99, no. 5, pp. 1-3, 2018, doi: 10.1080/0013838X.2018.1483635.

[19] R. Groenewold, R. Bastiaanse, L. Nickels, and M. Huiskes, "Perceived liveliness and speech comprehensibility in aphasia: the effects of direct speech in auditory narratives," Int. J. Lang. Commun. Disord., vol. 49, no. 4, pp. 486-497, 2014, doi: 10.1111/1460-6984.12080.

[20] R. Groenewold, R. Bastiaanse, and M. Huiskes, "Direct speech constructions in aphasic Dutch narratives," Aphasiology, vol. 27, no. 5, pp. 546567, 2013, doi: 10.1080/02687038.2012.742484. 